\title{
Adherence to Treatment and Glycemic Control in Patients with Type 2 Diabetes Mellitus: A 4-Year Follow-up PTM Bogor Cohort Study, Indonesia
}

\author{
Silma Kaaffah' \\ Pradana Soewondo ${ }^{2,3}$ \\ Woro Riyadina 4 \\ Fransiskus Samuel Renaldi \\ Rani Sauriasari (D) \\ 'Faculty of Pharmacy, Universitas \\ Indonesia, Depok, Indonesia; ${ }^{2}$ Division of \\ Endocrinology, Department of Internal \\ Medicine, Dr.Cipto Mangunkusumo \\ National Referral Hospital, Faculty of \\ Medicine Universitas Indonesia, Jakarta, \\ Indonesia; ${ }^{3}$ Metabolic, Cardiovascular \\ and Aging Cluster, The Indonesian \\ Medical Education and Research Institute, \\ Faculty of Medicine Universitas Indonesia, \\ Jakarta, Indonesia; ${ }^{4}$ National Institute of \\ Health Research and Development, \\ Ministry of Health Republic of Indonesia, \\ Jakarta, Indonesia
}

Correspondence: Rani Sauriasari Email rani@farmasi.ui.ac.id
Purpose: Large-scale evaluation of the treatment adherence in patients with type 2 diabetes mellitus (DM) in Indonesian is limited. We aim to evaluate the treatment adherence of Indonesian type 2 DM patients using national "big data" and investigate its association with glycemic parameters.

Patients and Methods: We analyzed baseline and fourth-year data sets from 2011 to 2018 obtained from the Indonesian Ministry of Health Cohort Study of Non-Communicable Disease Risk Factors in Bogor, West Java (the PTM Bogor Cohort Study). This was a retrospective cohort study in which the sample was divided into two groups. One group adhered to treatment from primary health centers and followed the prescribed medicine/ treatment regimen (treated group), while the other did not follow the treatment (untreated group). We evaluated changes in fasting blood glucose (FBG) and post-prandial blood glucose (PPBG) by controlling for other variables.

Results: From 5690 subjects, 593 were type 2 DM diagnosed and 342 were eligible at the baseline. At 4-year observation, 212 eligible patients remained, consisting of 62 subjects who adhered to treatment, and more than double that number who were untreated (150 subjects). More significant decreases in FBG and PPBG were found in the treated group (FBG 80.6\%, PPBG 90.3\%) than in the untreated group (FBG 42.0\%, PPBG 67.3\%). The results of the multivariate analysis showed that after 4 years observation, treated patients have reduced FBG 3.304 times more and PPBG 3.064 times more than untreated patients, with control factors such as decrease in LDL levels and use of oral drugs.

Conclusion: There were less than half as many treated patients as untreated patients involved in the PTM Bogor Study Group. At the fourth-year follow-up, treated patients experienced three times more significant decreases in FBG and PPBG than those who were untreated, even after being controlled by several confounding factors. Given the importance of these findings, it is suggested that immediate strategic action be taken to improve Indonesian patients' adherence to treatment.

Keywords: diabetes mellitus, fasting blood glucose, post-prandial blood glucose, treatment adherence, cohort

\section{Introduction}

Indonesia is ranked seventh globally for the prevalence of diabetes mellitus (DM), with around 10 million adult sufferers. ${ }^{1}$ Data from the Indonesian Association of Endocrinology (PERKENI) stated that DM in Indonesians over 15 years of age affected $10.9 \%$ of the population. ${ }^{2}$ Type $2 \mathrm{DM}$ with complications is the leading cause of death in Indonesia. ${ }^{3}$ Based on data from the World Economic Forum in 
April 2015, the potential losses due to non-communicable diseases in Indonesia in the 2012-2030 period will reach US\$ 4.47 trillion or 1.5 times the country's $2012 \mathrm{GDP}^{4}$

The DiabCare Asia 2008 study related to clinical control and complications in type $2 \mathrm{DM}$ in Indonesia collected information about management, complications, and regimens carried out personally by DM sufferers for the period 2008 to $2009 .{ }^{5}$ This was a non-interventional study with cross-sectional design of 1832 patients in Indonesia's secondary and tertiary health facilities. Of the patients in the study, $47.2 \%$ had a mean fasting blood glucose (FBG) level $>130 \mathrm{mg} / \mathrm{dL}(143.6 \mathrm{mg} / \mathrm{dL})$ and mean PPBG $>200 \mathrm{mg} / \mathrm{dL}(207.7 \mathrm{mg} / \mathrm{dL}) .{ }^{6}$ Of these, $81.3 \%$ of the total respondents used oral anti-diabetic drugs and $37.7 \%$ of the patients received insulin therapy. In line with this study, poor glycemic control in type 2 DM patients is also high in other countries in Asia, with Malaysia at 69.2\% and Thailand at $53.5 \%{ }^{7}$

Poor public awareness about DM makes it challenging to control blood glucose levels properly. Uncontrolled blood glucose levels cause various complications in other diseases. Studies have shown that awareness of the complexities involved in people's decision-making will help healthcare professionals to engage effectively with people living with diabetes. ${ }^{6}$ Several factors influence this phenomenon, such as age, duration of disease, treatment compliance, dietary factors, and physical activity, with all affecting blood glucose levels. ${ }^{8,9}$ Some research has stated that older people with a shorter illness period who received monotherapy showed better glycemic control. Patients with type 2 DM with low adherence levels had poor glycemic control compared to those with high levels of treatment adherence. ${ }^{10-12}$

In diabetic patients who did not know how to adhere to taking anti-diabetic medication, unintentional factors like irregular access to oral hypoglycemic agents and insulin can occur. ${ }^{13}$ Meanwhile, lack of patient-perceived benefit from taking medication, fear of side effects of drugs, and increasing complexity of regimens are intentional factors that lower medication adherence. ${ }^{14,15}$ Non-adherence to diabetic treatment recommendations can worsen clinical parameters, risk poor patient outcomes, and only permit suboptimal therapy benefits. The evaluation of medication adherence to type $2 \mathrm{DM}$ among patients taken from largescale Indonesian data is still limited. This cohort study aims to determine change in glycemic parameters in relation to treatment adherence and its relationship with various confounding factors.

\section{Materials and Methods}

Study Design, Ethical Approval, and

\section{Sample Participants}

This research was carried out as a retrospective cohort study using secondary data from the Indonesian Ministry of Health Cohort Study of Non-communicable Disease Risk Factors in five districts of Bogor City, West Java (the PTM Bogor Cohort Study) for the period 2011 to 2018. Two baseline observation points and fourth-year of monitoring were carried out by analyzing treatment adherence in type $2 \mathrm{DM}$ patients against glycemic parameters (considered as being controlled if the FBG value was 80 $130 \mathrm{mg} / \mathrm{dl}$ ). The data subset was collected in August 2019 at the Health Research and Development Agency (LITBANGKES), Indonesian Ministry of Health. This study ensured that patient data would be protected, as data on birthdates, addresses, and personal contacts are stored as archives only to be opened for research purposes.

We have received approval from the ethics committee in terms of data access from the accredited Bogor Cohort Study (statement letter number 07081903-058). Data sources were accessed based on permits obtained from the Indonesian Health Research and Development Agency. We also maintain participant privacy, such as confirmation that data is anonymized or kept confidential. The ethical approval of our research was obtained from the Ethics Committee of the Faculty of Medicine, University of Indonesia - Cipto Mangunkusumo Hospital with approval number 924/UN2.F1/ETIK/PPM.00.02/2019.

The research sample was calculated based on the WHO guidelines for sample-size determination in health studies used to test the difference between two populations. ${ }^{16}$ This retrospective cohort study involved 5690 people, from which 342 type 2 DM patients aged 25 years or older were identified. The sampling in this study followed a purposive sampling method. Patients with type $2 \mathrm{DM}$ who were involved in the PTM Bogor Cohort Study were followed up for 4 years. From all samples, 212 patients who met the inclusion and exclusion criteria of the study were found. The inclusion criteria were type 2 DM respondents in the PTM Bogor Cohort Study 2011-2018 who had complete blood test data (FBG, PPBG, lipid profile), blood pressure checks (systolic and diastolic), and anthropometric examinations (weight and height). This study's exclusion criteria were women with type $2 \mathrm{DM}$ who were pregnant and lactating and women with diabetes who used family planning (pills, injections, or implants). 
This study involved two types of groups. The first group adhered to some primary health centers and followed the prescribed medicine/treatment regimen (treated group) while the second group did not come and follow the treatment from primary health centers (untreated group). The parameters compared between the two groups focused on changes in glycemic parameters (FBG and PPBG) after 4 years of follow-up between the treated and untreated groups.

\section{Instruments}

Diagnosis: the diagnostic criteria for type $2 \mathrm{DM}$ were based on the American Diabetic Association (ADA) criteria and local criteria (PERKENI). This is based on FBG levels $\geq 126 \mathrm{mg} / \mathrm{dL}$ or $\mathrm{PPBG} \geq 200 \mathrm{mg} / \mathrm{dL}$ and/or classical symptoms. If a healthcare provider had told a participant they had diabetes or if a participant was on hypoglycemic medications, they were considered to have self-reported (previously diagnosed) diabetes, we call it diagnosed diabetes mellitus (DDM). Participants were considered to have undiagnosed diabetes if they responded "no" to these questions but otherwise met the ADA 2010 and PERKENI definition for diabetes, we call it undiagnosed diabetes mellitus (UDDM). ${ }^{2,17}$

Measurement of glucose levels was carried out by taking venous blood, which was measured at the local governmental primary health centers' laboratory that is part of this study. Study participants have been asked to fast (without caloric intake) for minimum 8 hours until the time of blood sampling in the laboratory. The amount of blood taken from each patient is $10 \mathrm{cc}$, which is then packaged in several special tubes to be processed by the local laboratory and within 3 hours some biological parameter values will be obtained. After the blood sampling, the patient was instructed to eat. Then, 2 hours after eating, their blood glucose levels must be measured again according to the applicable blood test procedure.

The entire implementation of data collection was coordinated by the person in charge of operations (specifically appointed) from the Government Health Center, Hospital, Public Health Center and the technical person in charge of data collection (which is specifically designated) namely researchers from the National Institute of Health Research and Development, Faculty of Medicine and Faculty of Public Health, University of Indonesia, Indonesian professional organizations and ad hoc researchers. The team were responsible for the accuracy, completeness of the data and the conduct of measurements and checks.

\section{Results}

Figure 1 shows that of the 5690 subjects of the Bogor Cohort Study, 593 were diagnosed with type 2 DM, of whom only 342 were eligible at baseline with complete blood laboratory examinations. After data cleaning, as shown in Figure 2, five subjects were found to have data missing. In addition, a further 125 subjects dropped out due to changes in adherence during the four years of monitoring. Figure 2 shows

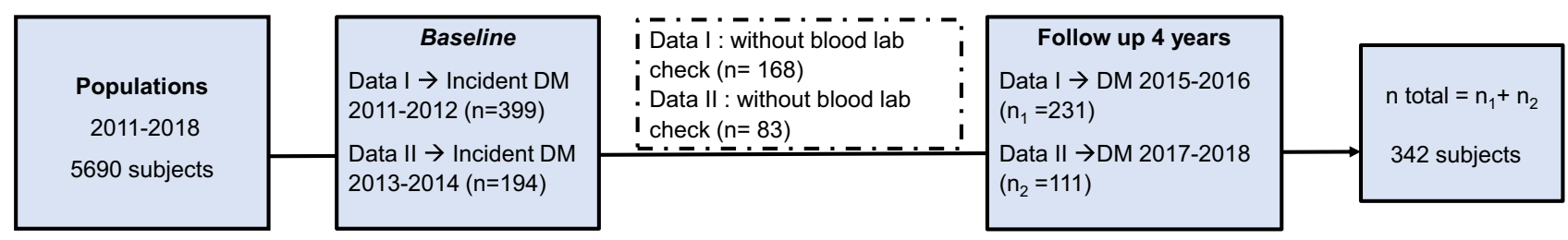

Figure I Flowchart of survey population sampling.

Notes: Prior to data collection, it is necessary to check whether the patient has type 2 diabetes mellitus and perform blood laboratory tests.

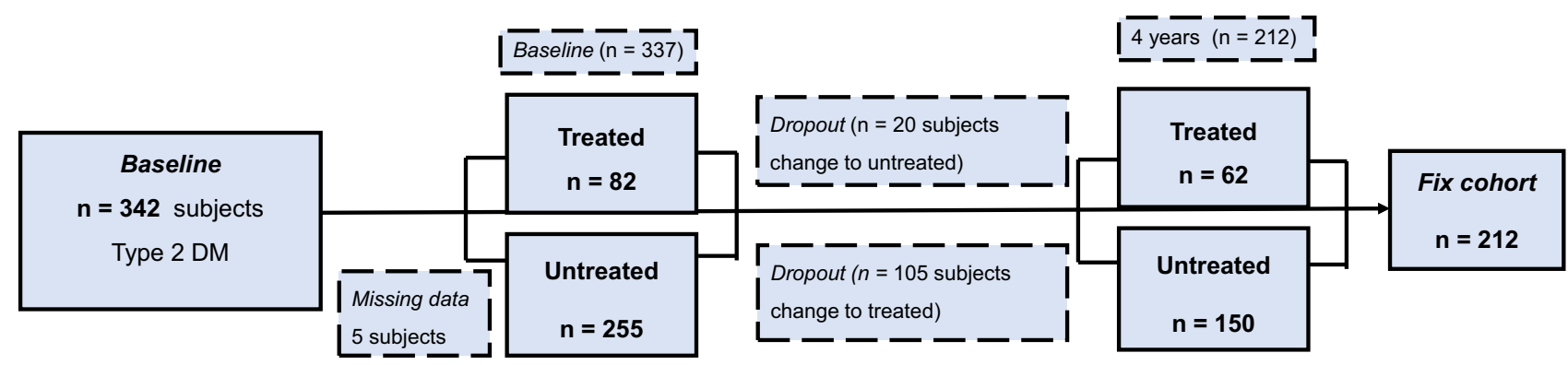

Figure 2 Flowchart of sample selection of treated group and untreated group on type 2 diabetes mellitus respondents Bogor cohort. Note: The treated group and untreated group criteria are based on 4 years of consistency in treatment. 
Table I Characteristics of Respondents

\begin{tabular}{|c|c|c|c|c|}
\hline \multicolumn{2}{|c|}{ Basic Characteristics } & \multirow{2}{*}{$\begin{array}{c}\text { Treated } \\
n=62(\%)\end{array}$} & \multirow{2}{*}{$\begin{array}{l}\text { Untreated } \\
n=150(\%)\end{array}$} & \multirow[t]{2}{*}{ P_value } \\
\hline & & & & \\
\hline \multirow[t]{2}{*}{ Gender } & Male & $18(29.0)$ & $4 I(27.3)$ & \multirow[t]{2}{*}{1.000} \\
\hline & Female & $44(71.0)$ & $109(72.7)$ & \\
\hline \multirow[t]{3}{*}{ Age, years } & $25-39$ & I (I.6) & $6(4.0)$ & \multirow[t]{3}{*}{0.002} \\
\hline & $40-59$ & $28(45.2)$ & $90(60.0)$ & \\
\hline & $>60$ & $33(53.2)$ & $54(36.0)$ & \\
\hline \multirow[t]{2}{*}{ Education } & Advanced & $25(40.3)$ & $70(46.7)$ & \multirow[t]{2}{*}{0.210} \\
\hline & Basic & $37(59.7)$ & $80(53.3)$ & \\
\hline \multirow[t]{2}{*}{ Employment } & Employed & $60(96.8)$ & $146(97.3)$ & \multirow[t]{2}{*}{1.000} \\
\hline & Unemployed & $2(3.2)$ & $4(2.7)$ & \\
\hline
\end{tabular}

that after 4 years of observation, only 212 patients were left as eligible subjects, of whom 62 were adherent and treated, while 150 were non-adherent and untreated. In other words, the proportion of non-adherent patients was more than double that of adherent patients.

Based on Table 1, it can be seen that of the total of 212 subjects with type 2 DM, the majority were female (153 out of 212 subjects). Most of the treated group was aged $>60$ years $(53.2 \%)$, while in the untreated group, more than half of the sample were aged $40-59$ years $(60 \%)$. In this study, most of the respondents had completed 9 years of education (junior high school) $(59.7 \%$ in the treated group and $53.3 \%$ in the untreated group). The majority of subjects were employed, at $96.8 \%$ of the treated group and $97.3 \%$ of the untreated group.

The researchers used data related to the types of pharmacological therapy used by respondents with type $2 \mathrm{DM}$ in Bogor. Of the 854 people with DM recorded in the Bogor cohort, samples were taken from 261 people with DM who took medication in the 2011-2018 period. Majority of the respondents took metformin (63.6\%), followed by sulfonylurea group drugs (32.2\%). Among the sulfonylurea group, glibenclamide was the most-used oral anti-diabetic, at $17.2 \%$ then glimepiride $10.2 \%$. Only $1.1 \%$ took insulin as pharmacological therapy for DM.

From the results of sampling shown in Figure 2, 212 respondents were eligible. For these subjects, we analyzed the influence of clinical characteristics on the decrease in glycemic parameters through bivariate analysis (Tables 2 and 3). Multivariate statistical analysis was used to evaluate the differences in various parameters between the treated and untreated groups. The results are presented in Tables 4 and 5 .

Table 6 compares the mean clinical outcomes between the treated group and untreated group in each baseline and fourth year of monitoring. Differences within each group against baseline and fourth year of monitoring were also assessed. Based on Table 6, the average FBG level in the treated group at baseline was $192.37 \mathrm{mg} / \mathrm{dL}$, and this mean decreased to $124.48 \mathrm{mg} / \mathrm{dL}$ at the fourth year of monitoring. The mean PPBG levels in the treated group also decreased from baseline of $301.34 \mathrm{mg} / \mathrm{dL}$ to $189.53 \mathrm{mg} /$ $\mathrm{dL}$ at the fourth year of monitoring. In addition, in the untreated group, the mean baseline FBG level of $125.03 \mathrm{mg} / \mathrm{dL}$ increased to $140.13 \mathrm{mg} / \mathrm{dL}$ at the fourth year of monitoring, while PPBG levels decreased from $243.77 \mathrm{mg} / \mathrm{dL}$ to $197.01 \mathrm{mg} / \mathrm{dL}$. The results showed that in terms of FBG levels, the treated group for 4 years achieved controlled blood glucose levels with a value of $\leq 130 \mathrm{mg} / \mathrm{dL}$. At year 4, mean weight was performed in the untreated group, because steady blood glucose levels were $>130 \mathrm{mg} / \mathrm{dL}$. The comparison baseline between the treated and untreated groups has been presented in Table 6 in column Pc. Based on column $P c$, significant difference test was seen between the treated and untreated groups at baseline (unpaired $t$-test). Since there was a large difference in baseline FBG and PPBG, we used changes in FBG and PPBG (decreasing and not decreasing) as clinical outcomes. 
Table 2 Bivariate Analysis of the Respondent's Clinical Characteristics in Relation to Decrease in the FBG Glycemic Parameter

\begin{tabular}{|c|c|c|c|c|c|c|c|c|}
\hline \multicolumn{2}{|l|}{ Clinical Characteristics } & \multicolumn{4}{|c|}{ Changes in FBG } & \multirow[t]{3}{*}{$p$} & \multirow[t]{3}{*}{$\mathbf{R R}$} & \multirow[t]{3}{*}{$95 \% \mathrm{Cl}$} \\
\hline & & \multicolumn{2}{|c|}{ Decreasing } & \multicolumn{2}{|c|}{ Not Decreasing } & & & \\
\hline & & $\mathbf{n}$ & (\%) & $\mathbf{n}$ & (\%) & & & \\
\hline \multirow[t]{2}{*}{ Treatment } & Treated & 50 & 80.6 & 12 & 19.4 & \multirow[t]{2}{*}{$<0.001$} & \multirow[t]{2}{*}{1.920} & \multirow[t]{2}{*}{$2.833-11.687$} \\
\hline & Untreated & 63 & 42.0 & 87 & 58.0 & & & \\
\hline \multirow[t]{2}{*}{ Oral drugs } & Yes & 44 & 60.3 & 29 & 39.7 & \multirow[t]{2}{*}{0.184} & \multirow[t]{2}{*}{1.214} & \multirow[t]{2}{*}{$0.945-1.560$} \\
\hline & No & 69 & 49.6 & 70 & 50.4 & & & \\
\hline \multirow[t]{2}{*}{ Insulin } & Yes & 2 & 66.7 & I & 33.3 & \multirow[t]{2}{*}{1.000} & \multirow[t]{2}{*}{1.255} & \multirow[t]{2}{*}{$0.558-2.822$} \\
\hline & No & 111 & 53.1 & 98 & 46.9 & & & \\
\hline \multirow[t]{2}{*}{ Comorbid hypertension } & No & 44 & 51.8 & 41 & 48.2 & \multirow[t]{2}{*}{0.821} & \multirow[t]{2}{*}{0.953} & \multirow[t]{2}{*}{$0.735-1.236$} \\
\hline & Yes & 69 & 54.3 & 58 & 45.7 & & & \\
\hline \multirow[t]{2}{*}{ Comorbid dyslipidemia } & No & 56 & 63.6 & 32 & 36.4 & \multirow[t]{2}{*}{0.016} & \multirow[t]{2}{*}{1.384} & \multirow[t]{2}{*}{$|.08|-1.77 \mid$} \\
\hline & Yes & 57 & 46.0 & 67 & 54.0 & & & \\
\hline \multirow[t]{2}{*}{ Body mass index } & Decreasing & 49 & 47.6 & 54 & 52.4 & \multirow[t]{2}{*}{0.137} & \multirow[t]{2}{*}{0.810} & \multirow[t]{2}{*}{$0.627-1.047$} \\
\hline & Not decreasing & 64 & 58.7 & 45 & 41.3 & & & \\
\hline \multirow[t]{2}{*}{ Cholesterol levels } & Decreasing & 62 & 60.8 & 40 & 39.2 & 0.049 & 1.311 & $1.017-1.691$ \\
\hline & Not decreasing & 51 & 46.4 & 59 & 53.6 & & & \\
\hline LDL levels & Decreasing & 69 & 63.3 & 40 & 36.7 & 0.004 & 1.482 & $1.136-1.932$ \\
\hline & Not decreasing & 44 & 42.7 & 59 & 57.3 & & & \\
\hline HDL levels & Not decreasing & 58 & 56.9 & 44 & 43.1 & 0.388 & 0.879 & $0.683-1.131$ \\
\hline & Decreasing & 55 & 50.0 & 55 & 50.0 & & & \\
\hline Systolic blood pressure & Decreasing & 59 & 57.3 & 44 & 42.7 & 0.322 & 1.156 & $0.898-1.488$ \\
\hline & Not decreasing & 54 & 49.5 & 55 & 50.5 & & & \\
\hline Diastolic blood pressure & Decreasing & 65 & 55.6 & 52 & 44.4 & 0.554 & 1.100 & $0.85 I-I .42 I$ \\
\hline & Not decreasing & 48 & 50.5 & 47 & 49.5 & & & \\
\hline
\end{tabular}

Notes: Data are expressed in $n(\%)$. The total number $(n)$ of the treated group $=62$. The total number $(n)$ of the untreated group $=150$. Bold values are statistically significant ( $p$-value $<0.05)$.

Abbreviations: FBG, fasting blood sugar; LDL, low-density lipoprotein; HDL, high-density lipoprotein; RR, relative risk; $95 \% \mathrm{Cl}, 95 \%$ confidence interval.

Tables 2 and 3 present respondents' clinical characteristics in relation to decreases in the levels of FBG and PPBG as glycemic parameters. The results show that a significantly greater proportion of respondents who adhered to treatment regimens at primary health centers for 4 years experienced a decrease in FBG levels (at $80.6 \%$ ) than respondents who did not adhere to treatment at primary health centers ( $p$-value $<0.001$ ).

Based on Table 2, it can be seen that in respondents who did not have comorbid dyslipidemia, a greater proportion $(63.6 \%)$ experiencing a decrease in FBG than respondents with comorbid dyslipidemia. Furthermore, respondents who experienced a decrease in cholesterol levels over 4 years also had a greater proportion of decreased FBG levels (at 60.8\%) than respondents with high cholesterol levels or those who had never decreased to normal limits in the 4 years $(46.4 \%)$. This was the same as the characteristics of respondents whose LDL levels had decreased in 4 years, $63.3 \%$ of whom experienced a decrease in FBG compared to $42.7 \%$ of the respondents who had never experienced a decrease in LDL levels to normal values. Clinical characteristics with a $p$-value of 
Table 3 Bivariate Analysis of the Respondent's Clinical Characteristics in Relation to the Decrease in the Glycemic Parameter of PostPrandial Blood Glucose (PPBG)

\begin{tabular}{|c|c|c|c|c|c|c|c|c|}
\hline \multicolumn{2}{|l|}{ Clinical Characteristics } & \multicolumn{4}{|c|}{ Changes in PPBG } & \multirow[t]{3}{*}{$p$} & \multirow[t]{3}{*}{$\mathbf{R R}$} & \multirow[t]{3}{*}{$95 \% \mathrm{Cl}$} \\
\hline & & \multicolumn{2}{|c|}{ Decreasing } & \multicolumn{2}{|c|}{ Not Decreasing } & & & \\
\hline & & $\mathbf{n}$ & $(\%)$ & $\mathbf{n}$ & (\%) & & & \\
\hline \multirow[t]{2}{*}{ Treatment } & Treated & 56 & 90.3 & 6 & 9.7 & \multirow[t]{2}{*}{0.001} & \multirow[t]{2}{*}{$1.34 \mid$} & \multirow[t]{2}{*}{$1.168-1.540$} \\
\hline & Untreated & 101 & 67.3 & 49 & 32.7 & & & \\
\hline \multirow[t]{2}{*}{ Oral drugs } & Yes & 61 & 83.6 & 12 & 16.4 & \multirow[t]{2}{*}{0.034} & \multirow[t]{2}{*}{1.210} & \multirow[t]{2}{*}{$1.04 I-1.407$} \\
\hline & No & 96 & 69.1 & 43 & 30.9 & & & \\
\hline \multirow[t]{2}{*}{ Insulin } & Yes & 3 & 100 & 0 & 0.0 & \multirow[t]{2}{*}{0.570} & \multirow[t]{2}{*}{1.357} & \multirow[t]{2}{*}{$1.252-1.472$} \\
\hline & No & 154 & 73.7 & 55 & 26.3 & & & \\
\hline \multirow[t]{2}{*}{ Comorbid hypertension } & No & 59 & 69.4 & 26 & 30.6 & \multirow[t]{2}{*}{0.270} & \multirow[t]{2}{*}{0.900} & \multirow[t]{2}{*}{$0.759-1.066$} \\
\hline & Yes & 98 & 77.2 & 29 & 22.8 & & & \\
\hline \multirow[t]{2}{*}{ Comorbid dyslipidemia } & No & 66 & 75.0 & 22 & 25.0 & \multirow[t]{2}{*}{0.916} & \multirow[t]{2}{*}{1.022} & \multirow[t]{2}{*}{$0.870-1.200$} \\
\hline & Yes & 91 & 73.4 & 33 & 26.6 & & & \\
\hline \multirow[t]{2}{*}{ Body mass index } & Decreasing & 21 & 67.7 & 10 & 32.3 & \multirow[t]{2}{*}{0.518} & \multirow[t]{2}{*}{0.902} & \multirow[t]{2}{*}{$0.697-1.166$} \\
\hline & Not decreasing & 136 & 75.1 & 45 & 24.9 & & & \\
\hline \multirow[t]{2}{*}{ Cholesterol levels } & Decreasing & 79 & 77.5 & 23 & 22.5 & 0.353 & 1.092 & $0.932-|.28|$ \\
\hline & Not decreasing & 78 & 70.9 & 32 & 29.1 & & & \\
\hline LDL levels & Decreasing & 83 & 76.1 & 26 & 23.9 & 0.577 & 1.060 & $0.903-1.244$ \\
\hline & Not decreasing & 74 & 71.8 & 29 & 28.2 & & & \\
\hline HDL levels & Not decreasing & 78 & 76.5 & 24 & 23.5 & 0.538 & 0.939 & $0.80 \mathrm{I}-1.10 \mathrm{I}$ \\
\hline & Decreasing & 79 & 71.8 & 31 & 28.2 & & & \\
\hline Systolic blood pressure & Decreasing & 80 & 77.7 & 23 & 22.3 & 0.312 & 1.099 & $0.938-1.289$ \\
\hline & Not decreasing & 77 & 70.6 & 32 & 29.4 & & & \\
\hline Diastolic blood pressure & Decreasing & 86 & 73.5 & 31 & 26.5 & 0.963 & 0.984 & $0.838-1.154$ \\
\hline & Not decreasing & 71 & 74.7 & 24 & 25.3 & & & \\
\hline
\end{tabular}

Notes: Data are expressed in $n(\%)$. The total number $(n)$ of treated group $=62$. The total number $(n)$ of the untreated group $=150$. Bold values are statistically significant ( $p$-value < 0.05)

Abbreviations: PPBG, post-prandial blood sugar; LDL, low-density lipoprotein; HDL, high-density lipoprotein; RR, relative risk; $95 \% \mathrm{Cl}$, $95 \%$ confidence interval.

$<0.25$ were then subjected to multivariate analysis. Based on data shown in Tables 2 and 3, of respondents who used oral drugs, 60.8\% had decreasing FBG levels and 83.6\% had decreasing PPBG levels within the 4 study years.

Table 3 shows that the percentage decrease in PPBG levels in respondents in treated groups with treatment at primary health centers was higher (at 90.3\%) than in untreated groups (67.3\%), with $p$-value of $<0.001$. Respondents who did not have comorbid dyslipidemia had a 75\% decrease in PPBG. Furthermore, respondents who experienced a decrease in cholesterol levels within 4 years also had reduced PPBG levels (77.5\%). Of respondents, $76.1 \%$ of those who experienced a decrease in their LDL levels within the 4 years also experienced a decrease in PPBG. Furthermore, based on bivariate analysis as presented in Tables 2 and 3, characteristics with a $p$-value of $<0.25$ were continued to multivariate analysis. Variables were assessed clinically for their 
Table 4 Multivariate Analysis of the Effect of Independent and Confounding Variables on the Decrease in FBG

\begin{tabular}{|l|l|l|l|c|c|c|}
\hline \multirow{2}{*}{ Model I } & \multicolumn{2}{|c|}{ Variable } & \multicolumn{2}{c|}{ RR } & P & 95\% CI \\
\hline \multirow{2}{*}{ Model 2 } & Treatment & $\begin{array}{l}\text { Treated } \\
\text { Untreated }\end{array}$ & Crude & 2.997 & $<0.001$ & $1.639-5.480$ \\
& Treatment & $\begin{array}{l}\text { Treated } \\
\text { Untreated }\end{array}$ & Adjusted & 3.304 & $<0.001$ & $1.727-6.321$ \\
\cline { 2 - 7 } & Oral drugs & $\begin{array}{l}\text { Yes } \\
\text { No }\end{array}$ & Decreasing \\
\cline { 2 - 7 } & Lot decreasing & & 0.808 & 0.368 & $0.507-1.286$ \\
& & & 1.532 & 0.037 & $1.026-2.289$ \\
\hline
\end{tabular}

Table 5 Multivariate Analysis of the Effect of Independent and Confounding Variables on the Decrease in PPBG

\begin{tabular}{|c|c|c|c|c|c|c|}
\hline & \multicolumn{2}{|c|}{ Variable } & \multicolumn{2}{|c|}{$\mathbf{R R}$} & \multirow{2}{*}{$\frac{P}{0.005}$} & \multirow{2}{*}{$\begin{array}{c}95 \% \mathrm{Cl} \\
(1.446-7.880)\end{array}$} \\
\hline Model I & Treatment & $\begin{array}{l}\text { Treated } \\
\text { Untreated }\end{array}$ & Crude & 3.376 & & \\
\hline \multirow[t]{3}{*}{ Model 2} & Treatment & $\begin{array}{l}\text { Treated } \\
\text { Untreated }\end{array}$ & Adjusted & 3.064 & 0.016 & (I.229-7.642) \\
\hline & Oral drugs & $\begin{array}{l}\text { Yes } \\
\text { No }\end{array}$ & & 1.332 & 0.419 & $(0.664-2.669)$ \\
\hline & LDL levels & $\begin{array}{l}\text { Decreasing } \\
\text { Not decreasing }\end{array}$ & & 1.185 & 0.530 & $(0.698-2.013)$ \\
\hline
\end{tabular}

effect on the decrease in the FBG and PPBG glycemic parameters.

Table 4 shows that the treated group was associated with reduced FBG levels 3.304 times more frequently than the untreated, after being controlled for decreasing LDL level and the use of oral drugs. Respondents with decreased LDL levels increased the incidence of decrease in FBG levels by 1.532 times. Table 5 shows that in the treated group, decreased PPBG levels 3.064 times more than the untreated, after being controlled for decreasing LDL levels and the use of oral drugs.

\section{Discussion}

In terms of basic characteristics, the results of this research follow the 2018 Indonesian Basic Health Research (Riskesdas) findings that the prevalence of type $2 \mathrm{DM}$ in women $(1.8 \%)$ is higher than in men $(1.2 \%)$ and that most patients are between the ages of 55 and 64 and 65 and $74 .{ }^{3}$ In line with a study in Sudan, these results show that females and males over 45 years old are more prevalent. ${ }^{18,19}$ In the PTM Bogor Cohort
Study, most of the respondents have 9-year compulsory basic education backgrounds (elementary school to junior high school), at $59.3 \%$ in the treated group and $53.3 \%$ in the untreated group. Most of the respondents were employed, at $96.8 \%$ in the treated group and $97.3 \%$ in the untreated group. According to research by Shao et al, people with diabetes in China on average had a secondary education $(60.80 \%)$ and were unemployed $(59.29 \%) .{ }^{20}$ Level of education affects the progression of diabetes, with those with a higher level of education having better knowledge and awareness about adherence and complications. ${ }^{21,22}$ Most of the respondents were treated with metformin (63.6\%) followed by sulfonylurea $(32.2 \%)$. These results are similar to the DiabCare Asia 2008 study "Outcomes on control and complication of type 2 diabetic patients in Indonesia" by Soewondo, ${ }^{5}$ a non-intervention study of data drawn from secondary and tertiary health centers in Indonesia. ${ }^{5}$ In the 1785 patients used in that study, biguanide (metformin) is the most commonly used drug at $59.26 \%$, followed by sulfonylurea at $56.58 \%$. 
Table 6 Difference in Clinical Outcomes Between Baseline and Fourth-Year Follow-Up of PTM Bogor Cohort Study Respondents

\begin{tabular}{|c|c|c|c|c|c|c|c|c|}
\hline \multirow[t]{2}{*}{ Variable } & \multicolumn{2}{|c|}{ Treated $(n=62)$} & \multicolumn{4}{|c|}{ Untreated $(n=150)$} & \multirow[t]{2}{*}{$P^{c}$} & \multirow[t]{2}{*}{$P^{d}$} \\
\hline & Baseline & $\begin{array}{c}\text { Fourth-Year } \\
\text { Follow-Up }\end{array}$ & $P^{\mathbf{a}}$ & Baseline & $\begin{array}{c}\text { Fourth-Year } \\
\text { Follow-Up }\end{array}$ & $P^{b}$ & & \\
\hline FBG & $192.37( \pm 74.62)$ & $124.48( \pm 22.37)$ & 0.001 & $125.03( \pm 47.07)$ & $140.13( \pm 59.44)$ & 0.001 & 0.001 & 0.001 \\
\hline PPBG & $301.34( \pm 87.32)$ & $189.53( \pm 52.90)$ & 0.001 & $243.77( \pm 76.98)$ & $197.01( \pm 96.15)$ & 0.001 & 0.001 & 0.001 \\
\hline BMI & $27.17( \pm 3.61)$ & $28.31( \pm 4.6 I)$ & 0.225 & $27.64( \pm 4.47)$ & $27.21( \pm 4.57)$ & 0.210 & 0.223 & 0.169 \\
\hline LDL & I44.58 ( \pm 29.90$)$ & $145.44( \pm 63.32)$ & 0.469 & $144.97( \pm 32.14)$ & $144.89( \pm 36.53)$ & 0.09 & 0.415 & 0.602 \\
\hline HDL & $48.58( \pm 9.31)$ & $47.05( \pm 10.13)$ & 0.884 & $49.43( \pm I I .44)$ & $51.01( \pm \mid 2.31)$ & 0.905 & 0.734 & 0.775 \\
\hline Total cholesterol & $223.89( \pm 37.55)$ & $214.15( \pm 50.32)$ & 0.325 & $220.71( \pm 36.73)$ & $225.07( \pm 42.21)$ & 0.68 & 0.659 & 0.532 \\
\hline $\begin{array}{l}\text { Systolic blood } \\
\text { pressure }\end{array}$ & $144.60( \pm 25.39)$ & $140.85( \pm 20.33)$ & 0.158 & $143.52( \pm 28.26)$ & $143.67( \pm 23.78)$ & 0.932 & 0.58 & 0.482 \\
\hline $\begin{array}{l}\text { Diastolic blood } \\
\text { pressure }\end{array}$ & $88.45( \pm 13.36)$ & $84.35( \pm 10.66)$ & 0.215 & $88.33( \pm 13.44)$ & $89.95( \pm 12.74)$ & 0.219 & 0.967 & 0.173 \\
\hline
\end{tabular}

Notes: Data are expressed in terms of means or average \pm standard deviation. Bold values are statistically significant $(P$-value $<0.05)$.

Abbreviations: FBG, fasting blood glucose; PPBG, post-prandial blood glucose; BMI, body mass index; LDL, low-density lipoprotein; HDL, high-density lipoprotein; P, the significance of the difference test with the $t$-test; $\mathrm{Cl} 95$. $P^{\mathrm{a}}$, significance difference test between times in the treated group (paired $t$-test); $P^{\mathrm{b}}$, significance difference test between times in the untreated group (paired $t$-test); $P^{c}$, significance difference test between treated and untreated groups at baseline (unpaired $t$-test); $P^{d}$, significance difference test between treated and untreated groups at the fourth-year follow-up (unpaired $t$-test).

Several studies comparing patients with excellent and poor glycemic control have shown that reasonable glycemic control is associated with age, duration of DM, drug utilization pattern, and medication adherence. ${ }^{9,13,23,24}$ The percentage of decreased FBG levels (80.6\%) and PPBG levels (90.3\%) in the treated group were higher than in the untreated group. This study indicates that type $2 \mathrm{DM}$ respondents who received treatment and adhered to it could reduce FBG levels and PPBG levels more successfully than non-adherent respondents. ${ }^{12,25,26}$ In this study, the treated group showed decreased FBG and PPBG within 4 years. After respondents obtained check-up laboratory results from the Health Research and Development Agency (every 2 years), the respondents were given a referral to a doctor for further DM diagnosis examination. Those respondents who attended the health centers and had an index category obese body mass I and II were referred to a nutritionist by the doctor. All respondents were monitored routinely after being examined by the Health Research and Development Agency every 2 years, being observed every 6 or 3 months in health centers. Patients with high levels of health literacy understood DM management, showed active attitudes toward seeking information, and had no difficulty in obtaining detailed information. ${ }^{22}$

Our findings show that in the untreated group of respondents, only $42 \%$ of the subjects experienced a decrease in FBG levels and only $67.3 \%$ of the subjects experienced a decrease in PPBG levels at the fourth year of monitoring. This result is different from the group of adherent respondents, where $80.6 \%$ of the subjects experienced a decrease in FBG levels and 90.3\% of them experienced a decrease in PPBG levels. This untreated group did not comply with visiting the health centers even though they had known that the test results from the check-up laboratory at LITBANGKES showed that their FBG and PPBG levels were abnormal based on the ADA criteria. ${ }^{4}$ We found that they still had the letter of referral, which means that they did not come to the primary health centers for further examination or get DM therapy, either because of fear (due to denial or lack of knowledge about DM) and/or lack of free time for treatment. Respondents also did not record therapy from baseline to fourth year of monitoring on the PTM Bogor cohort questionnaire. The results of this study showed decreasing of the mean FBG levels $(<130 \mathrm{mg} /$ $\mathrm{dL})$ and PPBG levels $(<200 \mathrm{mg} / \mathrm{dL})$ was controlled in the treated group in the fourth year of monitoring, while in the untreated group, this was not achieved because FBG levels remained $>130 \mathrm{mg} / \mathrm{dL}$. Another study showed that on bivariate analysis, low education level (below primary school completion), patient not being on insulin therapy, and lack of family assistance for taking medication were significantly associated with medication non-adherence. ${ }^{8,11,13}$ According to a study in 
India, diabetic patients not taking medication can occur from unintentional factors such as irregular access to health facilities, lack of patient-perceived benefit from taking medication, fear of side effects of drugs, and increasing complexity of regimen. Non-adherence to treatment recommendations can worsen clinical parameters, risk poor patient outcomes, and permit only suboptimal therapy benefits. ${ }^{13}$

In this study, we controlled for confounders through multivariate analysis. The multivariate analysis showed that the treated group did 3.304 times better for decrease in FBG and 3.064 better for decrease in PPBG than the untreated group, after being controlled decrease in LDL levels and use of oral drugs for 4 years. Lipid and glucose metabolism are interrelated, ${ }^{27-29}$ and this is evidenced by the presence of diabetic dyslipidemia, as characterized by an increase in triglycerides, high low-density lipoprotein (HDL-C) cholesterol, and high LDL or low-density lipoprotein particles. Hypertriglyceridemia and low HDL-C not only cause lipid abnormalities but also cause impaired glucose metabolism. ${ }^{29,30}$ In various studies that have been developed, there is a very significant correlation between fasting and postprandial glucose as a parameter of glucose and cholesterol. $^{31,32}$ FBG will be proportional to triglycerides (TG) and LDL but has an inverse ratio to HDL. Serum cholesterol and TG levels will be much higher in patients with poor glycemic conditions and lower HDL values. ${ }^{29,30}$ This correlation certainly provides an opportunity for LDL levels to be significant confounders because of the very substantial correlation with glycemic parameters.

Patients with type 2 DM in the PTM Bogor Cohort Study were initially encouraged to maintain a healthy diet and exercise regimen, followed by early treatment, which generally included one or more oral hypoglycemic agents or injection treatment to control glycemic parameters. A systematic review and meta-analysis showed that lifestyle interventions significantly lowered glycosylated hemoglobin (HbA1c) levels compared with usual care for patients with type $2 \mathrm{DM}^{33}$ Therapy adherence often provides drugs to control blood pressure, dyslipidemia, and other disorders, because patients often have more than three or four chronic conditions. Another study reported that adherence to therapy was defined as the extent of a person's commitment to taking medication, following a diet, and carrying out lifestyle changes, according to agreed recommendations from a healthcare provider. ${ }^{34-36}$

Based on the description above, the treated group significantly reduced glycemic parameters compared to the untreated group. The treated group in this study were respondents who attended the health facilities listed on the referral letter after receiving the results of the examination from the Research and Development Agency. Respondents also had a complete history of taking anti-diabetic medication at baseline through to 4-year follow-up. The limitations of this present study included its retrospective study design using secondary data. There is the possibility of incomplete data, human error in recording, and data entry or available data not being suitable for the requirements of the study. However, we conducted a cleaning technique and removed incomplete data relating to missing, unchecked, and unreadable information, for example, where a value is too small or too large, as happened in blood glucose levels, body mass index, lipid profiles, and blood pressure. The strict data inclusion criteria caused the reduction of sample numbers. However, the sample size in this study was more than the calculated minimum sample size.

\section{Conclusion}

There were less than half as many treated patients as untreated patients involved in the PTM Bogor Study Group. At the fourth-year follow-up, treated patients experienced three times more significant decreases in FBG and PPBG than those who were untreated, even after being controlled by several confounding factors. Given the importance of these findings, it is suggested that immediate strategic action be taken to improve Indonesian patients' adherence to treatment.

\section{Acknowledgments}

The authors are grateful to the Directorate of Research and Community Engagement, Universitas Indonesia, for financial support through PUTI Grant No. NKB-1274/UN2. RST/HKP.05.00/2020. We would like to thank the Health Research and Development Agency, Ministry of Health of the Republic of Indonesia assisted in collection of the PTM Cohort Bogor data subset and the drug compliance data survey in the field and supported this research.We also thank patients at PTM Bogor Cohort Study, Indonesia, for their great contribution to this study.

\section{Disclosure}

All authors report no conflicts of interest for this work and confirm there are no potential conflicts of interest with respect to the research, authorship, and publication of this article.

\section{References}

1. International Diabetes Federation. IDF Diabetes Atlas Ninth Edition 2019. International Diabetes Federation; 2019. Available from: https:// diabetesatlas.org/upload/resources/material/20200302_133351_ IDFATLAS9e-final-web.pdf. Accessed November 14, 2020. 
2. Soelistijo SA, Lindarto D, Decroli E, et al. Pedoman Pengelolaan Dan Pencegahan Diabetes Melitus Tipe 2 Dewasa [Guidelines for the Management and Prevention of Type 2 Diabetes Mellitus in Adults]. PB PERKENI; 2019. Indonesian.

3. Badan Penelitian dan Pengembangan Kesehatan [National Institute of Health Research and Development, Ministry of Health, Republic of Indonesia]. Laporan nasional riskesdas 2018 [Basic Health Research Report 2018].Kementerian Kesehatan Republik Indonesia; 2019. Available from: http://labdata.litbang.kemkes.go.id/images/down load/laporan/RKD/2018/Laporan_Nasional_RKD2018_FINAL.pdf. Accessed November 14, 2020. Indonesian.

4. American Diabetes Association. 2. Classification and diagnosis of diabetes: standards of medical care in diabetes. In: Standards of Medical Care in Diabetes - 2020. Vol. 43. American Diabetes Association;2020:S14-S31. Available from: https://care.diabetesjour nals.org/content/43/Supplement_1/S14. Accessed October 6, 2021.

5. Soewondo P, Soegondo S, Suastika K, Pranoto A, Soeatmadji DW, Tjokroprawiro A. The DiabCare Asia 2008 study - outcomes on control and complications of type 2 diabetic patients in Indonesia. Med J Indones. 2010;19(4):235-244. doi:10.13181/mji.v19i4.412

6. Ligita T, Wicking K, Francis K, Harvey N, Nurjannah I. How people living with diabetes in Indonesia learn about their disease: a grounded theory study. PLoS One. 2019;14(2):e0212019. doi:10.1371/journal. pone. 0212019

7. Mafauzy M. Diabetes mellitus in Malaysia. Med J Malaysia. 2006;61 (4):397-398

8. Kalogianni A. Factors affect in patient adherence to medication regimen. Health Sci J. 2011;5:157-158.

9. Aloudah NM, Scott NW, Aljadhey HS, Araujo-Soares V, Alrubeaan KA, Watson MC. Medication adherence among patients with type 2 diabetes: a mixed methods study. PLoS One. 2018;13 (12):e0207583. doi:10.1371/journal.pone.0207583

10. Adikusuma W, Qiyaam N. Adherence level and blood sugar control of type 2 diabetes mellitus patients who gets counseling and short messages service as reminder and motivation. Asian J Pharm Clin Res. 2018;11(2):219. doi:10.22159/ajpcr.2018.v11i2.22988

11. Aminde LN, Tindong M, Ngwasiri CA, et al. Adherence to antidiabetic medication and factors associated with non-adherence among patients with type-2 diabetes mellitus in two regional hospitals in Cameroon. BMC Endocr Disord. 2019;19(1):35. doi:10.1186/s12902-019-0360-9

12. Bagonza J, Rutebemberwa E, Bazeyo W. Adherence to anti diabetic medication among patients with diabetes in eastern Uganda; a Cross Sectional Study. BMC Health Serv Res. 2015;15(1):168. doi:10.1186/ s12913-015-0820-5

13. Basu S, Garg S, Sharma N, Singh MM, Garg S. Adherence to self-care practices, glycemic status and influencing factors in diabetes patients in a tertiary care hospital in Delhi. World J Diabetes. 2018;9 (5):72-79. doi:10.4239/wjd.v9.i5.72

14. Almeida C, Rocha C, Cruz R. Impact of adverse effects to oral antidiabetics on adherence and quality of life in patients with type 2 diabetes. Eur J Public Health. 2020;30(Supplement_2). doi:10.1093/ eurpub/ckaa040.020

15. Mohamed MR, Ramsdale E, Loh KP, et al. Associations of polypharmacy and inappropriate medications with adverse outcomes in older adults with cancer: a systematic review and meta-analysis. Oncologist. 2020;25(1):e94-e108. doi:10.1634/theoncologist.2019-0406

16. Lwanga SK, Lemeshow S; World Health Organization. Sample size determination in health studies: a practical manual. World Health Organization; 1991. Available from: https://apps.who.int/iris/handle/ 10665/40062. Accessed March 3, 2021.

17. Kshanti IAM, Wibudi A, Sibarani RP, et al. Pedoman pengelolaan glukosa darah mandiri [Guidelines for self-management of blood glucose]. PB PERKENI; 2019. Available from: https://pbperkeni.or. id/wp-content/uploads/2019/12/Pedoman-Pengelolaan-GlukosaDarah-Mandiri-2019.pdf. Accessed November 15, 2020. Indonesian.
18. Javed R, Mohsin SN, Adnan M, Naz S. Prevalence of type 2 diabetes among asymptomatic adults of Lahore Pakistan. Iran J Sci Technol Trans Sci. 2019;43(5):2185-2192. doi:10.1007/ s40995-019-00747-9

19. Omar SM, Musa IR, ElSouli A, Adam I. Prevalence, risk factors, and glycaemic control of type 2 diabetes mellitus in eastern Sudan: a community-based study. Ther Adv Endocrinol Metab. 2019;10:2042018819860071. doi:10.1177/2042018819860071

20. Shao Y, Liang L, Shi L, Wan C, Yu S. The effect of social support on glycemic control in patients with type 2 diabetes mellitus: the mediating roles of self-efficacy and adherence. $J$ Diabetes Res. 2017;2017:2804178. doi:10.1155/2017/2804178

21. Felix HC, Narcisse MR, Long CR, McElfish PA. Effects of a family diabetes self-management education intervention on the patients' supporters. Fam Syst Health. 2020;38(2):121-129. doi:10.1037/ fsh0000470

22. Kim S, Song Y, Park J, Utz S. Patients' experiences of diabetes selfmanagement education according to health-literacy levels. Clin Nurs Res. 2020;29(5):285-292. doi:10.1177/1054773819865879

23. Huang Y-M, Pecanac KE, Shiyanbola OO. "Why am i not taking medications?" Barriers and facilitators of diabetes medication adherence across different health literacy levels. Qual Health Res. 2020;30 (14):2331-2342. doi:10.1177/1049732320945296

24. Lilyana MTA, Pae K. Effectiveness education for diabetic melitus management in elderly with diabetic melitus. Adi Husada Nurs $J$. 2020;6(1):1-7. doi:10.37036/ahnj.v6i1.156

25. Pruette CS, Amaral S. Empowering patients to adhere to their treatment regimens: a multifaceted approach. Pediatr Transplant. 2020; e13849-e13849. doi:10.1111/petr.13849

26. Tiktin M, Celik S, Berard L. Understanding adherence to medications in type 2 diabetes care and clinical trials to overcome barriers: a narrative review. Curr Med Res Opin. 2016;32(2):277-287. doi:10.1185/03007995.2015.1119677

27. Mert KU, Başaran Ö, Mert GÖ, et al. Management of LDL-cholesterol levels in patients with diabetes mellitus in cardiology practice: real life evidence of under-treatment from the EPHESUS registry. Eur J Clin Invest. 2021:e13528. doi:10.1111/eci.13528

28. Goldberg IJ. Diabetic dyslipidemia: causes and consequences. J Clin Endocrinol Metab. 2001;86(3):965-971. doi:10.1210/jcem.86.3.7304

29. Haider K, Rehman K, Akash MSH. Impaired lipid metabolism in metabolic disorders. In: Akash MSH, Rehman K, Hashmi MZ, editors. Endocrine Disrupting Chemicals-Induced Metabolic Disorders and Treatment Strategies. Emerging Contaminants and Associated Treatment Technologies. Springer International Publishing; 2021:83-94. doi:10.1007/978-3-030-45923-9_5

30. Khan HA, Sobki SH, Khan SA. Association between glycaemic control and serum lipids profile in type 2 diabetic patients: hbA1c predicts dyslipidaemia. Clin Exp Med. 2007;7(1):24-29. doi:10.1007/ s10238-007-0121-3

31. Widyasari N. Hubungan karakteristik responden dengan risiko diabetes melitus dan dislipidemia kelurahan tanah kalikedinding [The relationship between respondent characteristics and the risk of diabetes mellitus and dyslipidemia in Tanah Kalikedinding Village [Relationship of Respondent's Characteristic with The Risk of Diabetes Mellitus and Dislipidemia at Tanah Kalikedinding]. Per Epid J. 2017;5(1):130-141. Indonesian. doi:10.20473/jbe. V5I12017.130-1413

32. Parhofer KG. Interaction between glucose and lipid metabolism: more than diabetic dyslipidemia. Diabetes Metab J. 2015;39 (5):353-362. doi:10.4093/dmj.2015.39.5.353

33. García-Molina L, Lewis-Mikhael A-M, Riquelme-Gallego B, CanoIbáñez N, Oliveras-López M-J, Bueno-Cavanillas A. Improving type 2 diabetes mellitus glycaemic control through lifestyle modification implementing diet intervention: a systematic review and meta-analysis. Eur J Nutr. 2020;59(4):1313-1328. doi:10.1007/s00394-019-02147-6 
34. Acuña-Zegarra MA, Santana-Cibrian M, Velasco-Hernandez JX. Modeling behavioral change and COVID-19 containment in Mexico: a trade-off between lockdown and compliance. Math Biosci. 2020;325:108370. doi:10.1016/j.mbs.2020.108370

35. Sakitri G, Astuti RK. Strategi kontrol gula darah dengan theory of planned behaviour pada pasien diabetes mellitus tipe 2 di puskesmas stabelan [Blood sugar control strategy with the theory of planned behavior in patients with type 2 diabetes mellitus at a Stabelan Health Center]. Profesi Prof Islam Media Publ Penelit. 2020;18(1):55-63. Indonesian. doi:10.26576/profesi.v18i1.42
36. Sagala R, Arozal W, Sauriasari R, Keban S. Evaluasi penerapan booklet dan edukasi apoteker pada pasien diabetes melitus tipe $2 \mathrm{di}$ rumah sakit mayapada tangerang [Evaluation of the application of booklets and pharmacist education in patients with type 2 diabetes mellitus at the Mayapada Hospital, Tangerang]. Pharm Sci Res. 2018;4(2). Indonesian. doi:10.7454/psr.v4i2.3742

\section{Publish your work in this journal}

Patient Preference and Adherence is an international, peer-reviewed, open access journal that focusing on the growing importance of patient preference and adherence throughout the therapeutic continuum. Patient satisfaction, acceptability, quality of life, compliance, persistence and their role in developing new therapeutic modalities and compounds to optimize clinical outcomes for existing disease states are major areas of interest for the journal. This journal has been accepted for indexing on PubMed Central. The manuscript management system is completely online and includes a very quick and fair peer-review system, which is all easy to use. Visit http:// www.dovepress.com/testimonials.php to read real quotes from published authors. 